\title{
KESESUAIAN Durio zibethinus Murr. DAN Nephelium lappaceum L. PADA LAHAN BLOK PEMANFAATAN TAHURA GUNUNG MENUMBING, BANGKA BARAT
}

\author{
Suitability of Durio zibethinus Murr. and Nephelium lappaceum L. on the Utilization Block \\ at Menumbing Mountain Grand Forest Park, West Bangka \\ Nuri Nursjahbani ${ }^{1}$, Omo Rusdiana $^{1}$, dan Darmawan ${ }^{2}$ \\ ${ }^{1}$ Departemen Silvikultur, Fakultas Kehutanan IPB \\ ${ }^{2}$ Departemen Ilmu Tanah dan Sumberdaya Lahan, Fakultas Pertanian, IPB
}

\begin{abstract}
The conversion of forests to non-forests by communities has resulted in the loss of forest ecosystems and a reduction in the area of land that can be utilized for nature tourism at Menumbing Mountain Grand Forest Park (MMGFP). Revegetation is needed by planting several types of forest vegetation that generate economic benefits for the community as well as attracting natural tourism in MMGFP utilization block such as durian (Durio zibethinus Murr.) and rambutan (Nephelium lappaceum L.). It is necessary to evaluate utilization block to ensure that both species grow well and productivity of fruits have optimal yield. This study aims to obtain recommendations for improvements of the land quality along with the suitable characteristics to be limiting the growth of durian and rambutan. Suitability evaluation of durian and rambutan refers to the land suitability classification criteria compiled by Indonesian Center for Agricultural Land Resources Research and Development by matching the growth requirements of both types with land utilization block characteristics. Durian and rambutan are considered to be marginally suitable (S3) for planting in most land utilization block. The limiting factor of durian and rambutan is rooting medium, i.e texture and nutrient retention, comprising $\mathrm{pH}$ or organic carbon (C-organic). The texture of the soil can not be modified because it is permanent. Soil pH can be increased through liming. The soil C-organic content can be increased through the application of organic fertilizer. After both efforts are made, the planted durian and rambutan are likely to grow well and productivity of the fruit will be optimal so that revegetation in the utilization block will be successful and problems faced in MMGFP will be solved.
\end{abstract}

Key words: Liming, marginally suitable, organic fertilizer, revegetation

\section{PENDAHULUAN}

Tahura Gunung Menumbing (TGM) merupakan salah satu Tahura yang baru ditetapkan pada 27 Juli 2016 dan terletak di Kecamatan Muntok, Kabupaten Bangka Barat. Walaupun belum lama ditetapkan, TGM telah mengalami permasalahan. Saat ini sebagian hutan di TGM telah dikonversi masyarakat menjadi area nonhutan. Area non-hutan salah satunya telah ditetapkan menjadi blok pemanfaatan karena banyaknya aktivitas budidaya masyarakat pada blok tersebut.

Konversi hutan menjadi non-hutan berdampak pada hilangnya sebagian ekosistem hutan dan penurunan luas lahan yang bisa dimanfaatkan untuk wisata alam TGM. Perlu dilakukan upaya revegetasi dengan menanami beberapa jenis tanaman kehutanan yang menghasilkan manfaat ekonomi bagi masyarakat sekaligus menarik minat wisata alam di TGM. Hal tersebut kemungkinan dapat menghentikan perambahan hutan oleh masyarakat serta meningkatkan minat wisatawan terhadap lahan yang telah direvegetasi di TGM. Area non-hutan yang saat ini telah terbentuk nantinya juga dapat kembali menjadi hutan.

Durian (Durio zibethinus Murr.) dan rambutan (Nephelium lappaceum L.) merupakan dua jenis pohon penghasil buah yang paling banyak dibudidayakan masyarakat Kecamatan Muntok. terdapat 19170 pohon durian serta 6125 pohon rambutan yang telah dibudidayakan di Kecamatan Muntok (BPS 2016). Durian dan rambutan perlu ditanami pada blok pemanfaatan TGM sebagai komponen pembentuk hutan yang ingin di bangun. Kedua jenis tersebut perlu dibudidayakan agar masyarakat mendapat manfaat ekonomi dari produksi buahnya. Jenis durian dan rambutan yang telah terkenal buahnya di Kecamatan Muntok juga dapat menjadi daya tarik wisata TGM.

Perlu dilakukan evaluasi lahan blok pemanfaatan untuk memastikan durian dan rambutan yang ditanam nantinya tumbuh dengan baik dan produktivitas buah yang dihasilkan optimal. Melalui evaluasi lahan, dapat diketahui faktor pembatas lahan blok pemanfaatan yang dimungkinkan akan membatasi pertumbuhan durian dan rambutan setelah ditanam. Perlu dilakukan upaya perbaikan terhadap faktor pembatas tersebut. Penelitian ini bertujuan untuk memperoleh rekomendasi perbaikan terhadap kualitas beserta karakteristik lahan yang dimungkinkan menjadi faktor pembatas pertumbuhan durian dan rambutan sehingga revegetasi di blok pemanfaatan dapat berhasil dan permasalahan di TGM dapat diatasi. 


\section{METODE PENELITIAN}

\section{Tempat dan Waktu Penelitian}

Penelitian dilaksanakan di Taman Hutan Raya Gunung Menumbing, Kecamatan Muntok, Kabupaten Bangka Barat, Provinsi Kepulauan Bangka Belitung. Sampel tanah yang diambil dari kawasan TGM dianalisis di Laboratorium Manajemen Sumberdaya Lahan, IPB. Penelitian dimulai sejak bulan Oktober 2016

\section{Alat dan Bahan}

Alat yang digunakan pada penelitian ini yaitu bor tanah, penggaris, plastik sampel, label, trashbag, clinometer, Global Positioning System (GPS), kamera, dan software ArcGIS 10.1. Bahan yang digunakan berupa sampel tanah. Bahan lainnya yang digunakan berupa data klimatologi dan data lereng di Tahura Gunung Menumbing.

\section{Pelaksanaan Penelitian Evaluasi Kesesuaian Lahan}

Dilakukan pencocokkan antara kriteria atau syarat tumbuh jenis durian dan rambutan (mengacu pada Balai Besar Litbang Sumberdaya Lahan Pertanian 2009) dengan karakteristik lahan blok pemanfaatan untuk mengetahui kelas kesesuaian lahan kedua jenis tanaman tersebut. Data karakteristik lahan digunakan untuk menilai kualitas lahan blok pemanfaatan (Tabel 1). Kualitas lahan yang dinilai berupa temperatur, ketersediaan air, ketersediaan oksigen, media perakaran, retensi hara, sodisitas, bahaya erosi, dan penyiapan lahan. Kualitas lahan berupa ketersediaan oksigen, media perakaran, retensi hara, sodisitas, bahaya erosi, dan penyiapan lahan dinilai dari data karakteristik lahan yang didapat dari hasil pengamatan, pengambilan sampel tanah, dan analisis 6 unit pengamatan pada blok pemanfaatan.

Sampel tanah diambil menggunakan bor tanah pada setiap titik amatan di kedalaman $0-30 \mathrm{~cm}$ dan $30-60$ $\mathrm{cm}$ untuk dianalisis sifat fisik berupa tekstur tanah dan sifat kimia berupa kapasitas tukar kation (KTK), pH, Corganik, dan Exchangable Sodium Percentage (dari perhitungan Natrium dapat ditukar) dengan metode standard seperti tertera pada Tabel 1. Penentuan titik pengamatan dan pengambilan sampel tanah menggunakan metode purposive sampling.

\section{Penarikan Kesimpulan Kelas Kesesuaian Lahan}

Setiap karakteristik lahan diklasifikasikan kesuaiannya terhadap persyaratan tumbuh jenis durian dan rambutan. Kesimpulan akhir ditentukan oleh karakteristik lahan dengan kelas kesesuian lahan yang terburuk. Prosedur penarikan kesimpulan ini didasarkan pada hukum minimum Liebig yang menyatakan bahwa kinerja pertumbuhan tanaman ditentukan oleh faktor yang terburuk (faktor pembatas) dan mempengaruhi pertumbuhan tanaman tersebut. Penarikan kesimpulan dari kriteria kelas kesesuaian lahan berupa hasil penilaian sangat sesuai (S1), cukup sesuai (S2), sesuai marginal (S3), dan tidak sesuai $(\mathrm{N})$ beserta faktor yang membatasi tanaman yang dievaluasi.

\section{Faktor Pembatas yang Perlu Diperbaiki}

Berdasarkan hasil penilaian kualitas dan karakteristik lahan, akan diketahui faktor pembatas bagi pertumbuhan jenis durian dan rambutan. Hal tersebut dapat menunjukkan kualitas beserta karakteristik lahan blok pemanfaatan yang perlu diperbaiki.

\section{HASIL DAN PEMBAHASAN}

\section{Kualitas dan Karakteristik Lahan Blok Pemanfaatan}

Jenis durian dan rambutan yang akan ditanam pada blok pemanfaatan TGM masih berasal dari Kecamatan Muntok. Kemungkinan keberhasilan hidup tanaman menjadi besar apabila penanaman yang dilakukan masih pada ruang lingkup wilayah yang sama. Namun untuk memastikan kedua jenis tanaman tersebut tumbuh dengan baik dan menghasilkan produktivitas buah yang optimal, perlu dilakukan evaluasi terhadap kualitas dan karakteristik lahan blok pemanfaatan TGM.

Kualitas lahan adalah sifat-sifat pengenal atau sifat yang kompleks dari sebidang lahan yang mempunyai pengaruh nyata terhadap pertumbuhan tanaman (Ritung et al. 2007). Kualitas lahan terdiri atas satu atau lebih karakteristik lahan. Kualitas lahan yang dinilai meliputi temperatur, ketersediaan air, bahaya erosi, penyiapan lahan, ketersediaan oksigen, media perakaran, retensi hara, dan sodisitas (BBSDLP 2009).

\section{Temperatur dan Ketersediaan Air}

Wilayah Tahura Gunung Menumbing yang terletak di Kabupaten Bangka Barat memiliki temperatur ratarata harian $27.07^{\circ} \mathrm{C}$, curah hujan tahunan $2197.58 \mathrm{~mm}$, dan kelembaban udara $81.22 \%$. Jenis durian dan rambutan yang dievaluasi sudah ditanam masyarakat di desa atau kelurahan yang berbatasan langsung dengan kawasan TGM. Hal tersebut memungkinkan jenis durian dan rambutan akan sesuai ditanam di dalam blok pemanfaatan TGM ditinjau dari temperatur dan ketersediaan airnya. Temperatur rata-rata harian dan kelembaban yang tidak terlalu ekstrim memungkinkan proses metabolisme tanaman berjalan dengan baik. Disamping itu, curah hujan yang besar juga akan memperbesar ketersediaan air yang dibutuhkan untuk pertumbuhan tanaman.

\section{Bahaya Erosi}

Bahaya erosi dapat ditinjau dari besarnya lereng pada lahan blok pemanfaatan. Lereng lahan di 6 titik pengamatan yaitu 5 sampai 7\% (Tabel 2). Berdasarkan hasil analisis lereng bentuk peta Rupa Bumi Indonesia skala (1 : 50 000), blok ini didominasi oleh lahan datar dengan lereng di bawah $8 \%$ dan sebagian kecil lahan memiliki lereng di atas $8 \%$. Kemungkinan terjadinya erosi pada lahan yang datar akan lebih rendah dibandingkan dengan lahan yang lebih curam. Selain itu, kondisi lahan yang datar akan memudahkan proses penanaman dan pemeliharaan tanaman. Sebaliknya, pengelolaan tanah pada lahan yang lebih curam 
membutuhkan lebih banyak tenaga dan modal dibandingkan dengan lahan yang datar (Hardjowigeno \& Widiatmaka 2007). Sebaiknya tanaman yang diambil manfaat ekonominya seperti durian dan rambutan ditanam pada lahan yang relatif datar saja.

\section{Penyiapan Lahan}

Kemudahan penyiapan lahan untuk diolah dapat ditinjau dari banyaknya batuan di permukaan dan singkapan batuan pada lahan. Blok pemanfaatan cenderung mudah diolah karena jumlah batuan di permukaan lahan ataupun batuan yang tersingkap di bawah 5\% (Tabel 2). Mekanisasi tidak diperlukan pada tanah yang mudah diolah seperti pada blok pemanfaatan sehingga dapat mengurangi biaya penyiapan lahan. Sedikitnya jumlah batuan pada lahan juga berdampak positif bagi tanaman durian dan rambutan. Akar tanaman akan lebih leluasa berkembang pada kondisi lahan tersebut (Achmad et al. 2012).

Tabel 1 Kualitas dan karakteristik lahan yang dinilai beserta sumber data

\begin{tabular}{|c|c|c|}
\hline Kualitas lahan & Karakteristik lahan & Sumber data \\
\hline Temperatur (tc) & Temperatur rerata $\left({ }^{0} \mathrm{C}\right)$ & $\begin{array}{l}\text { (BPS Kabupaten Bangka Barat 2016, 2014, } \\
\text { 2013, 2012) }\end{array}$ \\
\hline Ketersediaan air (wa) & $\begin{array}{l}\text { Kelembaban }(\%) \\
\text { Curah hujan }(\mathrm{mm})\end{array}$ & $\begin{array}{l}\text { (BPS Kabupaten Bangka Barat 2016, 2014, } \\
\text { 2013, 2012) } \\
\text { (Badan Pusat Statistik 2017) }\end{array}$ \\
\hline Ketersediaan oksigen (oa) & Drainase & Pengamatan lapang (Ritung et al. 2007) \\
\hline Media perakaran (rc) & $\begin{array}{l}\text { Tekstur } \\
\text { Bahan kasar }(\%) \\
\text { Kedalaman tanah }(\mathrm{cm})\end{array}$ & $\begin{array}{l}\text { Metode Pipet (Balai Penelitian Tanah 2009) } \\
\text { Pengamatan lapang (Hardjowigeno \& } \\
\text { Widiatmaka 2007) } \\
\text { Pengamatan lapang (Hardjowigeno \& } \\
\text { Widiatmaka 2007) }\end{array}$ \\
\hline Retensi hara (nr) & $\begin{array}{l}\mathrm{KTK}(\mathrm{cmol} / \mathrm{kg}) \\
\mathrm{pH} \\
\mathrm{C}-\text { org }(\%)\end{array}$ & $\begin{array}{l}\text { Metode titrasi (Balai Penelitian Tanah 2009) } \\
\text { Metode elektroda gelas (Balai Penelitian } \\
\text { Tanah 2009) } \\
\text { Metode walkley \& Black (Balai Penelitian } \\
\text { Tanah 2009) }\end{array}$ \\
\hline Sodisitas (xn) & $\begin{array}{l}\text { ESP }(\%) \text { dari data } \\
\text { Na-dd }(\mathrm{cmol} / \mathrm{kg})\end{array}$ & $\begin{array}{l}\text { Metode ekstrak NH4OAc N pH } 7.0 \text { (Balai } \\
\text { Penelitian Tanah 2009) }\end{array}$ \\
\hline Bahaya erosi (eh) & Lereng $(\%)$ & $\begin{array}{l}\text { Pengamatan lapang (Hardjowigeno \& } \\
\text { Widiatmaka 2007) }\end{array}$ \\
\hline Penyiapan lahan (lp) & $\begin{array}{l}\text { Batuan permukaan }(\%) \\
\text { Singkapan batuan }(\%)\end{array}$ & $\begin{array}{l}\text { Pengamatan lapang (Hardjowigeno \& } \\
\text { Widiatmaka 2007) } \\
\text { Pengamatan lapang (Hardjowigeno \& } \\
\text { Widiatmaka 2007) }\end{array}$ \\
\hline
\end{tabular}

Tabel 2 Karakteristik fisik lahan dan tanah blok pemanfaatan

\begin{tabular}{|c|c|c|c|c|c|c|c|}
\hline \multirow[b]{2}{*}{$\begin{array}{c}\text { Unit } \\
\text { pengamatan }\end{array}$} & \multicolumn{3}{|c|}{ Fisik lahan } & \multicolumn{4}{|c|}{ Fisik tanah } \\
\hline & $\begin{array}{c}\text { Lereng } \\
(\%)\end{array}$ & $\begin{array}{c}\text { Batuan } \\
\text { permukaan }(\%)\end{array}$ & $\begin{array}{l}\text { Singkapan } \\
\text { batuan }(\%)\end{array}$ & Drainase & $\begin{array}{c}\text { Bahan } \\
\operatorname{kasar}(\%)\end{array}$ & $\begin{array}{l}\text { Kedalaman } \\
\text { tanah }(\mathrm{cm})\end{array}$ & Tekstur \\
\hline $\mathrm{T} 1$ & 5 & $<5$ & $<5$ & Baik & $<15$ & 100 & llip \\
\hline $\mathrm{T} 2$ & 5 & $<5$ & $<5$ & Baik & $<15$ & 90 & $\operatorname{lp}$ \\
\hline $\mathrm{T} 3$ & 7 & $<5$ & $<5$ & Baik & $<15$ & 100 & llip \\
\hline $\mathrm{T} 4$ & 7 & $<5$ & $<5$ & Baik & $<15$ & 100 & 1lip \\
\hline T5 & 5 & $<5$ & $<5$ & Baik & $<15$ & 90 & llip \\
\hline T6 & 5 & $<5$ & $<5$ & Baik & $<15$ & 95 & $\mathrm{lp}$ \\
\hline Akumulasi & $5-7$ & $<5$ & $<5$ & Baik & $<15$ & $90-100$ & llip - lp \\
\hline
\end{tabular}

Ket: llip: lempung liat berpasir, lp: lempung berpasir

Tabel 3 Karakteristik kimia tanah blok pemanfaatan

\begin{tabular}{|c|c|c|c|c|c|}
\hline \multirow[b]{2}{*}{ Unit pengamatan } & \multicolumn{5}{|c|}{ Kimia tanah } \\
\hline & $\begin{array}{c}\text { C-org } \\
(\%)\end{array}$ & $\mathrm{pH}$ & $\begin{array}{c}\text { KTK } \\
(\mathrm{cmol} / \mathrm{kg})\end{array}$ & $\mathrm{Na}-\mathrm{dd}(\mathrm{cmol} / \mathrm{kg})$ & $\begin{array}{l}\text { ESP } \\
(\%)\end{array}$ \\
\hline $\mathrm{T} 1$ & $1.12(\mathrm{R})$ & $4.17(\mathrm{SM})$ & $14.52(\mathrm{R})$ & 0.07 (SR) & 0.48 (SR) \\
\hline $\mathrm{T} 2$ & $1.18(\mathrm{R})$ & $4.19(\mathrm{SM})$ & $9.43(\mathrm{R})$ & 0.09 (SR) & $0.95(\mathrm{SR})$ \\
\hline $\mathrm{T} 3$ & 0.29 (SR) & $4.39(\mathrm{SM})$ & $6.31(\mathrm{R})$ & 0.07 (SR) & $1.11(\mathrm{SR})$ \\
\hline $\mathrm{T} 4$ & 0.52 (SR) & $4.32(\mathrm{SM})$ & $7.14(\mathrm{R})$ & $0.11 \quad(\mathrm{R})$ & $1.54(\mathrm{SR})$ \\
\hline T5 & 0.60 (SR) & $4.05(\mathrm{SM})$ & $6.80(\mathrm{R})$ & 0.08 (SR) & $1.18(\mathrm{SR})$ \\
\hline T6 & $0.92(\mathrm{SR})$ & $4.07(\mathrm{SM})$ & $7.20(\mathrm{R})$ & 0.08 (SR) & $1.11(\mathrm{SR})$ \\
\hline Akumulasi & $0.8-1.2$ dan $<0.8$ & $<5.0$ & $<16$ & $0.07-0.11$ & $<15$ \\
\hline
\end{tabular}

Ket: R: rendah, SR: sangat rendah, SM: sangat masam 
Tabel 4 Penilaian kesesuaian durian pada lahan blok pemanfaatan

\begin{tabular}{|c|c|c|}
\hline \multirow{2}{*}{ Unit pengamatan } & \multicolumn{2}{|c|}{ Kesesuaian lahan } \\
\hline & Nilai data & Kelas kesesuaian lahan \\
\hline \multicolumn{3}{|l|}{ Temperatur (tc): } \\
\hline Temperatur rerata $\left({ }^{0} \mathrm{C}\right)$ & 27.07 & S1 \\
\hline \multicolumn{3}{|l|}{ Ketersediaan air (wa): } \\
\hline Curah hujan (mm) & 2197.58 & S1 \\
\hline Kelembaban $(\%)$ & 81.22 & S1 \\
\hline \multicolumn{3}{|l|}{ Ketersediaan oksigen (oa): } \\
\hline Drainase & Baik & S1 \\
\hline \multicolumn{3}{|l|}{ Media perakaran (rc): } \\
\hline \multirow[t]{2}{*}{ Tekstur } & - Agak halus (llip) (T1, T3, T4, T5) & S1 \\
\hline & - Agak kasar (lp) (T2, T6) & S3 \\
\hline Bahan kasar (\%) & $<15$ & S1 \\
\hline Kedalaman tanah $(\mathrm{cm})$ & $90-100$ & $\mathrm{~S} 2$ \\
\hline \multicolumn{3}{|l|}{ Retensi hara (nr): } \\
\hline $\mathrm{KTK}(\mathrm{cmol} / \mathrm{kg})$ & $<16$ & S2 \\
\hline $\mathrm{pH}$ & $<5.0$ & S3 \\
\hline \multirow[t]{2}{*}{ C-org (\%) } & - $0.8-1.2(\mathrm{~T} 1, \mathrm{~T} 2, \mathrm{~T} 6)$ & S2 \\
\hline & - $<0.8(\mathrm{~T} 3, \mathrm{~T} 4, \mathrm{~T} 5)$ & S3 \\
\hline \multicolumn{3}{|l|}{ Sodisitas (xn): } \\
\hline $\operatorname{ESP}(\%)$ & $<15$ & S1 \\
\hline \multicolumn{3}{|l|}{ Bahaya erosi (eh): } \\
\hline Lereng $(\%)$ & $<8$ & S1 \\
\hline \multicolumn{3}{|l|}{ Penyiapan lahan (lp): } \\
\hline Batuan permukaan (\%) & $<5$ & S1 \\
\hline Singkapan batuan (\%) & $<5$ & $\mathrm{~S} 1$ \\
\hline \multirow[t]{2}{*}{ Kelas kesesuaian lahan } & & S3nr (pH) \\
\hline & & $\begin{array}{l}\text { S3nr (C-org, pH) S3renr } \\
\text { (tekstur, pH) }\end{array}$ \\
\hline
\end{tabular}

Ket: S1 = sangat sesuai, S2 = cukup sesuai, S3 = sesuai marginal

(tekstur, pH)

Tabel 5 Penilaian kesesuaian rambutan pada lahan blok pemanfaatan

\begin{tabular}{|c|c|c|}
\hline \multirow{2}{*}{ Unit pengamatan } & \multicolumn{2}{|c|}{ Kesesuaian lahan } \\
\hline & Nilai data & Kelas kesesuaian lahan \\
\hline \multicolumn{3}{|l|}{ Temperatur (tc): } \\
\hline Temperatur rerata $\left({ }^{0} \mathrm{C}\right)$ & 27.07 & S1 \\
\hline \multicolumn{3}{|l|}{ Ketersediaan air (wa): } \\
\hline Curah hujan (mm) & 2197.58 & $\mathrm{~S} 1$ \\
\hline \multicolumn{3}{|l|}{ Ketersediaan oksigen (oa): } \\
\hline Drainase & Baik & S1 \\
\hline \multicolumn{3}{|l|}{ Media perakaran (rc): } \\
\hline \multirow[t]{2}{*}{ Tekstur } & - Agak halus (llip) (T1, T3, T4, T5) & S1 \\
\hline & - Agak kasar (lp) (T2, T6) & S3 \\
\hline Bahan kasar (\%) & $<15$ & S1 \\
\hline Kedalaman tanah $(\mathrm{cm})$ & $90-100$ & S2 \\
\hline \multicolumn{3}{|l|}{ Retensi hara (nr): } \\
\hline $\mathrm{KTK}(\mathrm{cmol} / \mathrm{kg})$ & $<16$ & S2 \\
\hline $\mathrm{pH}$ & $<4.5$ & S3 \\
\hline \multirow[t]{2}{*}{ C-org (\%) } & - $0.8-1.2(\mathrm{~T} 1, \mathrm{~T} 2, \mathrm{~T} 6)$ & S2 \\
\hline & - $<0.8(\mathrm{~T} 3, \mathrm{~T} 4, \mathrm{~T} 5)$ & S3 \\
\hline \multicolumn{3}{|l|}{ Sodisitas (xn): } \\
\hline $\operatorname{ESP}(\%)$ & $<15$ & S1 \\
\hline \multicolumn{3}{|l|}{ Bahaya erosi (eh): } \\
\hline Lereng $(\%)$ & $<8$ & S1 \\
\hline \multicolumn{3}{|l|}{ Penyiapan lahan (lp): } \\
\hline Batuan permukaan (\%) & $<5$ & S1 \\
\hline Singkapan batuan $(\%)$ & $<5$ & $\mathrm{~S} 1$ \\
\hline \multirow[t]{2}{*}{ Kelas kesesuaian lahan } & & S3nr (pH) \\
\hline & & $\begin{array}{l}\text { S3nr (C-org, pH) S3renr } \\
\text { (tekstur, pH) }\end{array}$ \\
\hline
\end{tabular}

Ket: S1 = sangat sesuai, S2 = cukup sesuai, S3 = sesuai marginal

\section{Ketersediaan Oksigen}

Ketersediaan oksigen di dalam tanah blok pemanfaatan salah satunya dapat ditinjau dari kondisi drainase tanah. Hasil pengamatan menunjukkan bahwa kondisi drainase tanah blok pemanfaatan tergolong baik
(Tabel 2). Kondisi drainase yang baik ditunjukkan dari tanah yang berwarna homogen tanpa bercak atau karatan besi dan/atau mangan serta warna gley (reduksi) pada lapisan 0 sampai $100 \mathrm{~cm}$ (Ritung et al. 2007). Ketiadaan bercak atau karat menunjukkan bahwa tanah 
tidak mengalami penggenangan dan pengeringan air tanah secara bergantian. Kondisi tanah tersebut menyebabkan oksigen tersedia dalam jumlah cukup di dalam tanah. Kandungan oksigen yang cukup memungkinkan akar tanaman durian dan rambutan yang terbiasa hidup di lahan kering dapat berkembang dengan baik (Hardjowigeno 2007).

\section{Media Perakaran}

Selain drainase tanah, perkembangan akar tanaman durian dan rambutan juga ditentukan oleh media perakarannya. Kondisi media perakaran dapat ditinjau dari tekstur, bahan kasar, dan kedalaman tanah. Berdasarkan hasil analisis yang disajikan pada Tabel 2, tekstur tanah blok pemanfaatan terdiri atas lempung liat berpasir (llip) dan lempung berpasir (lp). Lempung liat berpasir tergolong jenis tekstur yang agak halus dan lempung berpasir merupakan jenis tekstur yang tergolong agak kasar. Apabila tanah terlalu banyak mengandung pasir (kasar) maka kemampuan tanah tersebut dalam menjerap air dan hara menjadi rendah. Apabila tanah terlalu banyak mengandung liat (halus) memang kemampuannya dalam menjerap air dan hara besar namun tanah menjadi lebih padat sehingga aerasi tanah menjadi kurang baik (Hardjowigeno 2007). Tanah bertekstur lempung liat berpasir (agak halus) dan lempung berpasir (agak kasar) pada blok pemanfaatan dinilai memiliki aerasi yang masih cukup baik untuk perkembangan akar tanaman durian dan rambutan.

Adapun bahan kasar berupa partikel mineral tanah berdiameter di atas $2 \mathrm{~mm}$ tidak ditemukan dalam jumlah banyak pada tanah blok pemanfaatan. Hal tersebut mengindikasikan bahwa perakaran tanaman durian dan rambutan dapat leluasa tumbuh pada bagian permukaan ataupun bagian tanah yang lebih dalam. Akar tanaman dapat menembus kedalaman tanah yang cukup dalam yaitu $90-100 \mathrm{~cm}$.

\section{Retensi Hara}

Kemampuan tanah dalam meretensi hara dapat ditinjau dari beberapa sifat kimia tanah seperti kandungan karbon organik (C-organik), kemasaman tanah (pH), dan kapasitas tukar kation (KTK). Berdasarkan hasil analisis 6 sampel tanah yang diambil di blok pemanfaatan dan disajikan pada Tabel 3, kandungan C-organik tanah umumnya sangat rendah $(0.29-0.92 \%)$. Sebagian kecil lahan blok pemanfaatan juga memiliki tanah dengan kandungan C-organik yang rendah $(1.12-1.18 \%)$. Karbon organik tanah yang rendah mencerminkan kandungan bahan organik yang rendah di dalam tanah. Padahal bahan organik merupakan sumber unsur hara makro dan mikro yang dibutuhkan tanaman (Hardjowigeno 2007). Oleh karena itu C-organik tanah blok pemanfaatan perlu ditingkatkan minimal hingga di atas $2 \%$ untuk mendukung pertumbuhan tanaman durian dan rambutan (Pusat Penelitian Tanah 1983 dalam Hardjowigeno 2007). Tanah blok pemanfaatan mengandung $\mathrm{pH}$ yang sangat masam (4.05 - 4.39) dan KTK yang rendah (6.31 $-14.52 \mathrm{cmol} / \mathrm{kg}) . \mathrm{pH}$ yang sangat masam menyebabkan unsur hara sulit diserap oleh akar tanaman karena unsur hara tersebut terikat oleh unsur lainnya di dalam tanah.
Adapun KTK yang rendah mengindikasikan rendahnya kemampuan tanah dalam menjerap unsur hara (Hardjowigeno 2007). pH dan KTK tanah yang terlalu rendah perlu ditingkatkan dengan beberapa perlakuan. $\mathrm{pH}$ dan KTK perlu ditingkatkan masing-masing hingga di atas 5.5 dan $16 \mathrm{cmol} / \mathrm{kg}$ (Pusat Penelitian Tanah 1983 dalam Hardjowigeno 2007).

\section{Sodisitas}

Sodisitas dapat dinilai dari kandungan Exchangeable Sodium Percentage (ESP) atau persentase natrium dapat ditukar (Na-dd). Hasil analisis Na-dd dan ESP dari 6 sampel tanah disajikan pada Tabel 3. Kandungan Na-dd pada blok pemanfaatan umumnya tergolong sangat rendah $(0.08-0.09 \mathrm{cmol} / \mathrm{kg})$. Sebagian kecil lahan juga memiliki kandungan Na-dd yang rendah $(0.11 \mathrm{cmol} / \mathrm{kg})$. Kandungan ESP tanah pada blok pemanfaatan tergolong sangat rendah $(0.48-1.54 \%)$. Nilai tersebut menguntungkan bagi pertumbuhan tanaman durian dan rambutan yang akan ditanam pada blok pemanfaatan. ESP yang tinggi (di atas 20\%) akan menyebabkan pertumbuhan tanaman terhambat atau rusak karena meningkatnya tekanan osmotik di permukaan akar. ESP yang tinggi juga menunjukkan keadaan fisik tanah yang buruk untuk pertumbuhan tanaman (Hardjowigeno \& Widiatmaka 2007).

\section{Kesesuaian Jenis Durian dan Rambutan pada Lahan Blok Pemanfaatan}

Dilakukan penilaian kelas kesesuaian durian terhadap lahan blok pemanfaatan. Jenis durian dinilai sesuai marginal (S3) untuk ditanam pada sebagian besar lahan blok pemanfaatan berdasarkan Tabel 4. Kelas sesuai marginal menunjukkan bahwa lahan blok pemanfaatan memiliki pembatas yang cukup besar. Pembatas tersebut akan meningkatkan masukan yang diperlukan (Hardjowigeno \& Widiatmaka 2007). Faktor yang dimungkinkan membatasi jenis durian tumbuh optimal adalah media perakaran (rc) yaitu tekstur dan retensi hara (nr) baik itu $\mathrm{pH}$ ataupun $\mathrm{C}$-organik tanah blok pemanfaatan. Beberapa daerah di blok pemanfaatan dinilai sesuai marginal dengan faktor pembatas $\mathrm{pH}$ saja. Beberapa daerah lainnya dinilai sesuai marginal dengan faktor pembatas kombinasi antara C-organik dan $\mathrm{pH}$. Terdapat pula daerah di blok pemanfaatan yang dinilai sesuai marginal dengan faktor pembatas kombinasi antara tekstur dan $\mathrm{pH}$.

Jenis rambutan juga dinilai sesuai marginal (S3) untuk ditanam pada sebagian besar lahan blok pemanfaatan berdasarkan Tabel 5. Faktor yang dimungkinkan membatasi jenis rambutan tumbuh optimal adalah media perakaran (rc) yaitu tekstur dan retensi hara (nr) baik itu $\mathrm{pH}$ ataupun $\mathrm{C}$-organik tanah blok pemanfaatan. Faktor pembatas rambutan sama seperti faktor pembatas durian yang akan muncul sebagai pembatas tunggal ataupun kombinasi dengan pembatas lainnya di lahan blok pemanfaatan. Sebaiknya dilakukan perbaikan pada faktor pembatas yang masih dapat diperbaiki. Potensi lahan dimungkinkan akan meningkat setelah dilakukan upaya perbaikan sehingga produktivitas tanaman durian dan rambutan yang optimal akan tercapai. 
Faktor Pembatas dan Rekomendasi Perbaikan Lahan Blok Pemanfaatan

Faktor pembatas lahan blok pemanfaatan yaitu media perakaran yaitu tekstur dan retensi hara baik itu $\mathrm{pH}$ ataupun $\mathrm{C}$-organik tanah. Karakteristik lahan berupa tekstur tanah tidak dapat diperbaiki karena sifatnya yang permanen atau sulit berubah. Nilai $\mathrm{pH}$ dan C-organik tanah merupakan karakteristik lahan yang masih dapat diperbaiki. Nilai $\mathrm{pH}$ tanah dapat ditingkatkan melalui pengapuran dengan dosis yang sesuai. Pengapuran dapat meningkatkan $\mathrm{pH}$ tanah blok pemanfaatan hingga mendekati netral. Unsur hara menjadi mudah larut dalam air pada $\mathrm{pH}$ tanah yang mendekati netral, sehingga unsur hara tersebut akan mudah diserap oleh akar tanaman durian dan rambutan (Hardjowigeno 2007).

Karbon organik tanah yang rendah mengindikasikan rendahnya kandungan bahan organik yang menjadi salah satu sumber hara di dalam tanah. Tanah tersebut sebaiknya diberi bahan organik dalam bentuk pupuk organik untuk meningkatkan sumber hara (Hardjowigeno 2007). Pemberian pupuk organik juga dapat meningkatkan kemampuan tanah blok pemanfaatan dalam menahan air dan hara (KTK). Pupuk organik dapat dibuat dari bahan tanaman hasil pembabatan saat penyiapan lahan tanam pada blok pemanfaatan. Pupuk organik yang diberikan pada lubang tanam dimungkinkan akan meningkatkan Corganik, ketersediaan hara, dan KTK tanah di sekitar perakaran bibit durian dan rambutan yang ditanam di blok pemanfaatan.

\section{SIMPULAN}

Jenis durian dan rambutan dinilai sesuai marginal (S3) untuk ditanam pada sebagian besar lahan blok pemanfaatan TGM. Faktor pembatas jenis durian dan rambutan adalah media perakaran yaitu tekstur dan retensi hara baik itu $\mathrm{pH}$ ataupun $\mathrm{C}$-organik tanah. Faktor pembatas tersebut akan muncul sebagai pembatas tunggal ataupun kombinasi dengan pembatas lainnya di lahan blok pemanfaatan. Tekstur tanah tidak dapat diperbaiki karena sifatnya yang permanen. $\mathrm{pH}$ tanah dapat ditingkatkan melalui pengapuran dengan dosis yang sesuai. Kandungan C-organik tanah dapat ditingkatkan melalui pemberian pupuk organik. Setelah kedua upaya perbaikan tersebut dilakukan, durian dan rambutan yang ditanam dimungkinkan akan tumbuh dengan baik dan produktivitas buah yang dihasilkan akan optimal sehingga revegetasi di blok pemanfaatan akan berhasil dan permasalahan di TGM akan dapat diatasi.

\section{DAFTAR PUSTAKA}

Achmad M, Munir A, Suhardi. 2012. Penerapan SIG untuk kesesuaian lahan tanaman kacang tanah di Kabupaten Gowa. Jurnal AgriTechno. 1(5): 53-63.

Badan Pusat Statistik. 2012. Bangka Barat dalam Angka. Bangka (ID): BPS Kabupaten Bangka Barat.

Badan Pusat Statistik. 2013. Bangka Barat dalam Angka. Bangka (ID): BPS Kabupaten Bangka Barat.

Badan Pusat Statistik. 2016. Kecamatan Muntok dalam Angka. Bangka (ID): BPS Kabupaten Bangka Barat.

Badan Pusat Statistik. 2014. Statistik Daerah Kabupaten Bangka Barat. Bangka (ID): BPS Kabupaten Bangka Barat.

Badan Pusat Statistik. 2016. Statistik Daerah Kabupaten Bangka Barat. Bangka (ID): BPS Kabupaten Bangka Barat.

Badan Pusat Statistik. 2017. Jumlah curah hujan dan jumlah hari hujan di stasiun pengamatan BMKG, 2011-2015 [Internet]. [Diunduh 2017 Jul 31]. Tersedia pada: https://www.bps.go.id/index.php/linkTabelStatis/195 $\underline{9}$

Balai Besar Litbang Sumberdaya Lahan Pertanian. 2009. Contoh evaluasi lahan [Internet]. [Diunduh 2017 Jan 27]. Tersedia pada: http://bbsdlp.litbang.pertanian.go.id/contoh.php

Balai Besar Litbang Sumberdaya Lahan Pertanian. 2009. Kriteria durian [Internet]. [Diunduh 2016 Okt 20]. Tersedia pada: http://bbsdlp.litbang.pertanian.go.id/kriteria/durian.p $\underline{\mathrm{hp}}$

Balai Besar Litbang Sumberdaya Lahan Pertanian. 2009. Kriteria rambutan [Internet]. [Diunduh 2017 Jul 5]. Tersedia pada: http://bbsdlp.litbang.pertanian.go.id/kriteria/rambuta n.php

Balai Penelitian Tanah. 2009. Analisis Kimia Tanah, Tanaman, Air, dan Pupuk. Bogor (ID): Balai Penelitian Tanah.

Hardjowigeno S. 2007. Ilmu Tanah. Jakarta (ID): Akademika Pressindo.

Hardjowigeno S, Widiatmaka. 2007. Evaluasi Kesesuaian Lahan \& Perencanaan Tataguna Lahan. Yogyakarta (ID): Gadjah Mada University Press.

Ritung S, Wahyunto, Agus F, Hidayat. 2007. Panduan Evaluasi Kesesuaian Satuan Lahan: dengan contoh peta arahan penggunaan satuan lahan Kabupaten Aceh Barat. Bogor (ID): Balai Penelitian Tanah dan World Agroforestry Center. 